Ministerstwo Nauki

i Szkolnictwa Wyższego

Digitalizacja archiwalnych numerów czasopisma naukowego Analecta Cracoviensia 1-24 (1969-1992)

i ich publikacja w otwartym dostępie - zadanie finansowane w ramach umowy 672/P-DUN/2017 ze środków

Ministra Nauki i Szkolnictwa Wyższego przeznaczonych na działalność upowszechniającą naukę

\title{
TEOLOGIA ROKU LITURGICZNEGO WEDEUG P. GUÉRANGERA OSB
}

Prosper Louis Pascal Guéranger (1805-1875) znany jest głównie jako wznowiciel benedyktynów we Francji i pierwszy opat odbudowanego klasztoru w Solesmes oraz jako inicjator ruchu liturgicznego. W całej swej różnorodnej działalności wskazał on na istotną funkcję liturgii tak w życiu całego Kościoła, jak też poszczególnego chrześcijanina. Do podstawowych jego dzieł tyczących liturgii należą trzy tomy Institutions Liturgiques (1840-1851) i przede wzsystkim piętnaście tomów L'Année liturgique, z których pierwszy ukazał się w 1841 roku a ostatnie sześć tomów zostało wydanych po śmierci autora, pod redakcją L. Frommage OSB. To właśnie dzieło stanowiące prawdziwą encyklopedię chrześcijańskiej heortologii, służyło przez dziesiątki lat kształtowaniu liturgicznej pobożności w szerokich kręgach katolickiego społeczeństwa. Ono też stanowi podstawowe źródło poznania teologicznej koncepcji roku liturgicznego P. Guérangera.

W zasadzie nie usiłował on stworzyć teologicznej teorii roku liturgicznego. „Nie zamierzam - pisał we wstępie do L'Année liturgique umieszczać w tym dziele swoich własnych myśli, ani tworzyć jakiegoś systemu odnośnie tajemnic roku kościelnego" ${ }^{1}$. Nie był to zresztą czas na tworzenie systemów, kiedy trzeba było „we Francji Kościół wznosić z ruin i reorganizować" ${ }^{2}$. Dlatego też Opat z Solesmes, pisząc dzieło poświęcone liturgii roku kościelnego, stawiał sobie cele wyłącznie duszpasterskie. Pragnął „służyć za tłumacza Kościołowi świętemu, ażeby wiernym ułatwić zrozumienie modlitwy liturgicznej na każdy czas, każdy dzień i każdą niemal godzinę" " ${ }^{3}$. Choć jego komentarze uwzględniają bardzo szeroko i element historyczny, to jednak wszystkie te objaśnienia ostatecznie zmierzają do tego, by wiernych wprowadzić $\mathrm{w}$ sedno liturgii

1 L'Anné liturgique (= AL), L'Avent, Paris 18744, Préface XVII.

2 E. Hocedez, Histoire de la théologie au XIXe siècle, t. II, Epanouissement de la théologie, 1830-1870, Paris 1952, 261; por. tamże, 264.

3 AL, L'Avent, Préface, XVII. 
roku kościelnego. „Cała nasza troska - jak pisał - polega na uchwyceniu zamierzeń Ducha Swiętego w poszczególnych okresach roku liturgicznego" 4 .

Mimo wyżej wspomnianych zastrzeżeń Opata, można podjąć próbę odszukania i uporządkowania idei przewodnich omawianego dzieła, by poznać, na czym, zdaniem Guérangera polega „misterium” roku kościelnego i jakie realizuje cele, aby w ten sposób dotrzeć do jego teologii roku liturgicznego.

\section{KOSCIÓ MIEJSCEM DZIAEANIA CHRYSTUSA I DUCHA SWIĘTEGO}

Choć na pierwszy plan swego dzieła wysunął Guéranger cele duszpasterskie, dzięki czemu liturgię roku kościelnego ukazuje przede wszystkim jako swoistą szkołę życia chrześcijańskiego, to równocześnie wskazuje bardzo wyraźnie na źródło uświęcającej funkcji tej szkoły. Jest nim obecność w Kościele Chrystusa i Ducha Swiętego kontynuującego zbawcze dzieło poprzez liturgię ofiary eucharystycznej, sakramentów, poprzez liturgię uroczystości, świąt, dni poświęconych Maryi i świętym oraz poprzez liturgię poszczególnych okresów roku kościelnego. Opisując to Boże działanie w roku liturgicznym, posługuje się terminem „misterium" (mystère) ${ }^{5}$. Termin ten w jego ujęciu zawiera bogatą treść, określane są nim bowiem tajemnice Boga samego, życie Jezusa Chrystusa i zbawcze wydarzenia, przede wszystkim misterium paschalne; używa dalej tego terminu, gdy mówi o Bożym działaniu w sakramentach, o liturgii roku kościelnego, o poszczególnych obrzędach liturgicznych czy wreszcie gdy pisze o samym uświęcającym działaniu Boga. Terminem tym określa więc Guéranger cały dynamizm zbawczego dzieła, którego źródło tkwi w Bogu a realizuje się poprzez sakramenty i liturgię roku kościelnego w duszy konkretnego, poszczególnego człowieka. „Te Boże mysteria, które celebrujemy w ciągu roku przynoszą nowe życie i nową radość", podtrzymują ,witalność Kościoła" 6 .

Termin „misterium” i bogata rzeczywistość określane tym terminem

${ }^{4}$ Tamże.

5 Guéranger używa tego terminu bardzo często. Nie sposób wyliczać wszystkich miejsc. Dlatego będą podane tylko cytaty wybrane dla ilustracji zagadnienia. Najczęściej posługuje się formą liczby pojedynczej obok liczby mnogiej oraz formą przymiotnikową. Na przykład: „mystère de sainte liturgie” (AL, Le Temps Pascal, t. I, Paris $\left.1875^{3}, 23\right)$, „mystère du divin Paraclet” (tamże, 31), "le mystère de l'unité" - chodzi o Eucharystię (tamże, 215). Ale "mystère de foi" - w sensie prawd wiary (tamże, 140), w takim wypadku niekiedy używa zamiennie słowa ,le secret" w liczbie pojedynczej lub mnogiej: „les secrets" (tamże, 149) lub „Le grand secret du ciel" - gdy mówi o Trójcy Świętej (AL, Le temps après la Pentecôte, t. I, Paris $1885^{5}, 141$ ). Przymiotnikowe formy: kanon to „prière mystérieuse" (AL, Le Temps Pascal, t. I, 74); paschal - ,symbole mystérieux du Christ - Lumière (tamże, 189); fragment Ewangelii - „récit mystérieux” (tamże, 380).

6 AL, Le Temps Pascal, t. I, 381. 
wiąże się ściśle z koncepcją Kościoła. To bowiem w Kościele, jak pisze Opat z Solesmes, „objawia się Jezus Chrystus i tajemnice jego życia” ?. Chcąc więc dotrzeć do pojęcia misterium roku kościelnego w ujęciu Guérangera trzeba wprzód poznać jego określenie Kościoła.

Łatwo daje się zauważyć, że ujmuje on Kościół wyraźnie w podwójnym aspekcie: widzi w nim „widzialną, zewnętrzną”, ,prawdziwą i doskonałą społeczność”, złożoną z dwóch rodzajów członków, „kierujących i kierowanych, nauczających i słuchających", w której najwyższą władzę ma papież, ale widzi też w Kościele „duchową społeczność” ${ }^{8}$. Jak dla Opata z Solesmes liturgia nie była tylko rubrycystyką, tak i w Kościele dostrzegał on nie tylko prawną społeczność religijną, ale widział w nim i bardzo wyraźnie uwydatnił jego duchową strukturę. Na określenie tak pojętego Kościoła posługuje się różnymi terminami biblijnymi, a więc Kościół to „Nowy Lud”, zrodzony przez chrzest, którego typem jest lud Boży Starego Testamentu, z całą swoją historią. Członkowie tego nowego ludu są konsekwentnie „wybranym plemieniem, królewskim kapłaństwem, świętym narodem, ludem (Bogu) na własność przeznaczonym" (1 P 2,9). Kościól dalej to „Królestwo”, „Owczarnia”, „Swiątynia”, której wierni stanowią „żywe kamienie”, „Ciało Chrystusa”, „Ciało mistyczne’. Najczęściej jednak spośród tych i kilku jeszcze innych określeń ${ }^{9}$, używa on dwóch terminów. Pierwszym z nich to - „Oblubienica Chrystusa" ${ }^{10}$, termin zapożyczony $\mathrm{z}$ języka biblijnego; drugim określeniem Ko-

7 AL, L'Avent, Préface, XV.

8 AL, Le Temps Pascal, t. II, Paris $1868^{2}$ 159, 169, 185, 284, 328 i 332. Obronie władzy papieskiej w Kościele, którą traktował jako centrum, z którego pochodzi władza biskupów, kapłanów, a przede wszystkim obronie nieomylności nauczania, następców Piotra „odnośnie prawd objawionych, czy to dogmatycznych czy moralnych", poświęcił następujące dzieła: De la monarchie pontificale à propos du livre de Mgr l'évêque de Surs, Paris 1870; Défense de l'Eglise Romaine contre les accusations du R.P. Gratry, Paris 1870; Deuxième défense de l'Eglise Romaine contre les accusations du R.P. Gratry, Paris 1870; Troisième défense de l'Eglise Romaine contre les accusations du R.P. Gratry, Paris 1870.

9 Inne jeszcze określenia stosowane do Kościoła przez autora w L'Année liturgique: „L'Eglise de Dieu” — Al, L'Avent, 378; AL, Le Temps de Noël, t. II, Paris 18733, 437; AL, Le Temps de la Septuagésime, Paris 18743, 404, 427; "L'Eglise du Christ" - AL, Le Temps de Noël, t. II, 426, 456; AL, La Passion et la Semaine Sainte, Paris 18754, 400; "L'Eglise du ciel" i L'Eglise de la terre”- AL, Le Temps de Carême, Paris $1875^{4}, 609$.

Szczególnie drogim dla Guérangera był tytuł Chrystusa-Króla. Widząc sens historii w realizacji „Królestwa Jezusa Chrystusa i Jego Kościoła” (Essai sur le naturalisme contemporain, Paris 1858, LXVII), nazywa Kościół - Królestwem, Chrystusa - Wodzem, a wiernych - żołnierzami Chrystusa. Por. P. de Puniet, Dom Guéranger de la Culte du Christ-Roi, ,La vie bénédictine”, 2(1938) 79_85; 3(1938) 111-120; AL, Le Temps Pascal, t. III, Paris 18813, 240-243.

${ }_{10}$ „L'Epouse du Christ”, „L'Epouse de Jésus”: AL, L'Avent, VI, VII, XVIII, X, XIV, XVII, 13, 57, 117, 192, 269, 333, 335, 400, 401; AL, Le Temps de Noël, t. I, Paris $1875^{3}, 27,44,98,183$; t. II, 220, 304, 305; 401, 426; AL, La Passion et la Semaine Sainte, 18, 347, 553, 554; AL, Le Temps Pascal, t. I, 27; t. II, 159, 203, 274; Por. 2 Kor 11, 2; Ap 21, 2; 22, 17. Konsekwentnie - Chrystus Oblubieńcem Kościoła - „Epoux de l'Eglise”: AL, L'Avent, VI, 15; 287, 335, 360, 499, 500; AL, Le Temps de Noël, t. I, 402, 403; AL, Le Temps de Septuagésime, 404; AL, Le Carê- 
ścioła jest słowo „Matka” ${ }^{11}$, „ulubiony zwrot pierwszych pisarzy i Ojców Kościoła" 12 .

Terminy te wskazują na źródła jego eklezjologii, którymi są Biblia i nauka Ojców Kościoła, równocześnie świadczą, jak bardzo podkreślał duchową, wewnętrzną stronę Kościoła i jego nadprzyrodzony dynamizm, wynikający z zewnętrznej więzi Kościoła z Chrystusem (Oblubieniec Oblubienica) i jego członkami (Matka - dzieci). Ten związek Kościoła z Chrystusem tak dalece i głęboko pojmuje, że Kościół określa po prostu jako „dopełnienie Chrystusa" (le Complément du Christ et sa plénitude) ${ }^{13}$. Kościól z natury rzeczy będąc Oblubienicą Chrystusa, stanowi z Nim „,jedno ciało”, „Ciało Chrystusa”. Kościól, wyjaśnia Guéranger w innym miejscu, „nie jest niczym innym jak ciałem Człowieka-Boga i jego mistycznym dopełnieniem”, jest kontynuacją, „,naturalnym następstwem Tajemnicy Wcielenia" ${ }^{14}$, dlatego Kościół jest ożywiony „tym sa-

me, 230; AL, La Passion et la Semaine Sainte, 16, 18, 675. Takie ujęcie Kościoła prezentuje też w De la monarchie pontificale, Paris 1870, 131-132: „Jésus Christ qui est la Voie, la Vérité et la Vie, a promis demeurer avec son Eglise jusqu’à la consommation des siècles. Il lui a envoyé son Esprit pour l'animer et la régir, comme notre âme régit et anime notre corps. Ce divin Esprit maintient en elle l'unité et l'invariabilité de la foi, en sorte qu'elle est l'Epouse du Christ, n'ayant ni tache ni ride (Ef 5,27$)$, la colonne et soutien de la vérité $(1 \mathrm{Tm} 3,15)$... C'est l'Eglise considérée dans son ensemble qui est appelée par saint Paul l'Epouse du Christ". Termin "Oblubienica" w zastosowaniu do Kościoła to ,temat klasyczny" w Nowym Testamencie - por. Mt 22, 1-14; 24, 1-13; Mk 2, 19; Ek 5, 34; J 3, 29: 2 Kor 11, 2; Ef 5, 21-33; Ap 19, 7; 21, 2-9; 22-17. Por. O.A. Jankowski OSB: Myśl Boża o Kościele objawiona w Piśmie świętym, „Ateneum Kapłańskie”, 66 (1963) 1-18; Komentarz praktyczny do Nowego Testamentu, (praca zbiorowa), Poznań 1975, 381. Tę problematykę porusza między innymi i F. Szreder CR, w artykule: Ważniejsze metafory eklezjologiczne w Piśmie świętym, „Ruch Biblijny i Liturgiczny", 6 (1962) 321-329.

11 Por.: "notre Mère", "notre Mère la sainte Eglise": AL, L'Avent, 14, 19, 66, 334, 339; AL, Le Temps de Noël, t. I, 27, 32, 336; AL, Le Temps de Septuagésime, 57, 119; "Mère commune": AL, Le Temps de Septuagésime, 124; AL, Le Carême, 382, 394, 494, 538; „Mère et Maîtresse": AL, L'Avent, 291. 316; AL, La Passion et la Semaine Sainte, 631; Członkowie Kościoła Konsekwentnie stanowią jej dzieci "ses enfants": AL, Le Temps de Septuagésime, 192, 268, 346, 405; AL, Le Carême, $51,77,265,490$. Kościół rodzi je przez chrzest. AL, La Passion et la Semaine Sainte, 707,720 .

12 W. Zaleski, Mistyczne Ciało Chrystusa, Poznań 1962, 13.

13 AL, Le Temps après la Pentecôte, t. I, 204; "L'Eglise nous dit l'Apôtre, est le complément du Christ et sa plenitude (Ef 1, 23)".

14 AI, Le Temps après la Pentecôte, t. II, Paris 1884², 123: „Epouse, elle ne l'est en effet cue par l'union qui la fait mystiquement avec le Christ un seul corps". Tamże, 181: „Car l'Eglise n'étant autre chose que le corps de l'Homme-Dieu et son mystique complément, la formation de l'Eglise, ses acroissements, ne sont pour saint Paul que la suite régulière de l'Incarnation, le développement continu du mystère de l'Incarnation, apparu dans la crèche aux célestes principautés". Chrystus jest zasadą, źródłem życıa i świętości dla Kościola. Tamże, 114, 118, 120, 128, 180-183. Ekklezjologię w ujęciu Guérangera przedstawił J.F. Lemaire analizując kilka jego ,niewydanych szkiców o Kościele w referacie wygłoszonym na Sympozjum poświęconym P. Guérangerowi w Solesmes w dniach 10-12.X.1975, pt. Les Quatres essais inachevés de dom Guéranger sur l'Eglise, Solosmes 1975. Ukazując związek jego eklezjologii z tajemnicą Wcielenia, Lemaire zwraca uwagę na podobieństwo koncepcji Guérangera z nauką J.A. Möhlera „pioniera powrotu do 
mym, jednym życiem, życiem Człowieka-Boga Chrystusa". Chrystus jest „głową tego mistycznego Ciała, które w Duchu Świętym formuje i rozwija we wszystkich jego członkach" 15 .

Związek Kościoła z Tajemnicą Wcielenia ukazuje Guéranger jeszcze głębiej, omawiając relacje Ducha Swiętego - Parakleta z Chrystusem i Kościołem. Duch Swięty bowiem przygotował świat na przyjście Syna Bożego, poprzez działalność proroków (JL 2,29; Ez 36,25-27). On był sprawcą Wcielenia, towarzyszył działalności Mesjasza. Jezus z kolei objawia Ducha Swiętego i zesłał Go na Apostołów, powierzając Mu swój Kościół. Duch Swięty, powtarza Guéranger za Augustynem, jest „duszą świętego Kościoła" ${ }^{16}$. Wypełniając swą misję formuje On Kościół-Oblubienicę i Królestwo Chrystusa, towarzyszy mu, podtrzymuje go, zbawia i uświęca ${ }^{17}$, Duch Swięty, będąc „węzłem jedności i odwiecznej miłości Ojca i Syna"18, tak jak był sprawcą zjednoczenia dwóch natur w jednej Osobie Syna Bożego w Tajemnicy Wcielenia, tak też teraz jest sprawcą jedności w Kościele. On to jednocząc całe Ciało z Głową sprawia, że członki są „,wszczepione” (incorporés) w Chrystusa ${ }^{19}$. Owocem tego jednoczacego działania Ducha Swiętego jest ,jedna wiara, jeden symbol wiary, jedna głowa widzialna rządząca i jeden co do istoty kult" oraz świętość Kościoła-Oblubienicy i jej „płodność”, dzięki której Kościół jest Matką, która poprzez sakramenty rodzi nowe dzieci, rozszerzając się po świecie i odnosząc wciąż nowe zwycięstwa nad atakami złego ducha ${ }^{20}$. To działanie Ducha Świętego w Kościele realizuje się między innymi właśnie poprzez liturgię roku kościelnego.

Kościół mocą Ducha Świętego zjednoczony z Chrystusem partycypuje w jego godności kapłańskiej, jest powołany do kultu, do składania ofia-

Ojców Kościoła w eklezjologii". Möhler podobnie jak Guéranger, widział w Kościele „kontynuację Wcielenia”. Różnią się oni jedynie tokiem rozwoju swych koncepcji teologicznych. Möhler, jak podkreśla Lemaire, wychodzi od Zesłania DuchaSwiętego, aby dotrzeć do tajemnicy Wcielenia, Guéranger zaś rozpoczynając od tajemnicy Wcielenia dochodzi do tajemnicy Zmartwychwstania i działania Ducha Świętego (16-17). Autor cytowanego artykułu widzi też w eklezjologii Guérangera zarysy teologii Kościola przedstawionej w Konstytucji Lumen Gentium (8-18).

15 Tamże, 182.

16 „Czym dusza jest dla ciała ludzkiego, tym Duch Święty jest dla Ciała Chrystusowego, którym jest Kościół" (Sermo CCLVII, In die Pentecostes). Por. AL, Le Temps de la Pentecôte, t. III, Tours 193616, 449, 451, 454; AL, Le Temps Pascal, t. III, 451,454 .

17 Tamże, 323: „la mission de former l'Eglise épouse et empire du Christ, de l'assister, de la maintenir, de sauver et de sanctifier les âmes". Dzięki temu ta Oblubieniea jest ,świętym Kościołem". Toteż Guéranger tak chętnie i często posługuje się tym określeniem. Por. AL, L'Avent, 46; AL, Le Temps de la Septuagésime, 66, 121, 132, 260; AL, Le Carême, 59, 145, 222, 274, 295, 342, 435, 468, 487, 554; AL, La Passion et la Semaine Sainte, 15, 16, 18, 30, 249, 268, 284, 324, 425, 531, $547,553,559,627-682,685,719$.

18 AL, Le Temps Pascal, t. III, 337-338, 451-452.

19 Tamże, 484: „Sa mission est de nous unir à Jésus si étroitement que nous lui soyons incorporés". Por. tamże, 448, 450, 451, 452, 453.

20 Por. tamże, 421, 424, 429, 450, 470, 489. 
ry. Jak Duch Święty czyni z poszczególnych członków Kościoła Swiątynię Boga (1 Kor 3, 16), pobudza do modlitwy, udziela światła, mocy (Gal $4,6)$, tak też Duch Swięty jest natchnieniem dla Kościoła-Oblubienicy w zorganizowaniu kultu, liturgii. „To w Kościele - jak wielokrotnie podkreśla Guéranger - przebywa Duch Boży”, który zstąpił nań, „jakoby uderzenie gwałtownego wiatru" i pod postacią ,,języków jakby z ognia" (Dz 2,2) i odtąd ,zamieszkał na stałe w tej szczęśliwej Oblubienicy" ${ }^{21}$. To właśnie Duch Swięty jest duszą kultu i uświęcenia, które sprawuje Kościół poprzez liturgię całego roku kościelnego ${ }^{22}$. „Duch Swięty jest w Kościele zasadą jego życia. On sam podsuwa jemu swe prośby i życzenia, swoją pieśń chwały, zapala entuzjazmem i żarliwością. I dlatego przez wieki, ani we dnie ani w nocy, nie ustaje chwalba Boża na ustach Kościoła. Słowo jego, rozbrzmiewając dźwięcznym głosem, trafia wprost w serce Oblubieńca” 23. Ten sam Duch Swięty, który „ożywiał Psalmistę i Proroków”, ożywia dziś Kościół, do wyśpiewania „,pieśni nowej” (Ps 143), ku czci Pana Zastępów w liturgii całego roku ${ }^{24}$. Liturgia całego roku kościelnego jest więc, jak pisał, „Misterium Ducha Swiętego (...) istniejącym z jego inspiracji” 25. Dlatego liturgia roku kościelnego jest „,szczególnym miejscem działania Ducha Świętego" 26 a modlitwa liturgiczna i udział w liturgii jest ,pierwszym źródłem światła, życia i modlitwy osobistej" 27.

Kościół inspirowany przez Ducha Swiętego poprzez wieki kształtuje liturgię całego roku, „wyznacza” do czytania w czasie liturgii poszczególne fragmenty Pisma Swiętego, ,,podsuwa do medytacji” poszczególne epizody życia Jezusa Chrystusa, organizuje modlitwy, posty, czuwania, zachęca do uczynków miłosierdzia. To Kościół ukazuje rolę Eucharystii w naszym życiu, to on "celebruje rocznice” wielkich wydarzeń Zbawienia, ukazując ich „boski dramat”, to Kościół wreszcie „czci pamięć" świętych ${ }^{28}$. Stąd też istotną rzeczą w liturgii roku kościelnego jest, abyśmy „uczyli się od Kościoła”, byśmy na jego zachęty byli „uważni i wierni”, abyśmy chcieli „,zrozumieć myśl Kościoła”, „wniknąć w jego

21 AL, L'Avent, Préface, V-VI.

22 Ten związek Ducha Świętego z Kościolem i liturgią - bardzo mocno akcentuje Guéranger. Stąd też, jak to wydobywa z jego notatek niewydanych, Lemaire, Opat $\mathrm{z}$ Solesmes tak chętnie odwoluje się do "świadectwa Kościoła jako mie js ca teologicznego (podkreślenie Guérangera). „Kościołowi bowiem zarówno w jego nauczaniu jak i działaniu towarzyszy Duch Swięty, darząc swą nieomylnością". To w Kościele obok oficjalnego nauczania, liturgia „s tanowi pryncypalne narzędzie Tradycji Kościoła" (znów podkreślenie Guérangera). (Les quatres essais, 7).

23 AL, L'Avent, Préface, VI.

24 Tamże, VII.

${ }_{25}$ Tamże, XXIII.

26 AL, Le Temps Pascal, t. III, 475.

27 Tamże.

28 AL, La Passion et la Semaine Sainte, 13, 27; AL, Le Carême, 35, 36, 37, 560. 
ducha", w ,,jego uczucia" 29. Będąc bowiem pod działaniem Kościoła w liturgii roku, jesteśmy tym samym pod „działaniem Ducha Swiętego" ${ }^{0}$. Przez Kościół bowiem przychodzą do nas wszystkie jego łaski. On nas formuje, zbawia, uświęca, jednoczy z Jezusem Chrystusem i do niego upodabnia. „My synowie nicości powołani jesteśmy, aby stać się przez działanie Słowa i Ducha, synami Ojca niebieskiego" ${ }^{31}$. Tak zjednoczeni z Kościołem i Chrystusem, składamy „pełny hołd Ojcu” — hołd Głowy i Członków. W ten sposób wypełniamy „dokonane na chrzcie” oddanie się „w posiadanie Ojcu, Synowi i Duchowi Swiętemu” w życiu „na chwałę Ojca i Syna i Ducha Swiętego" 32. Cały kult, który składa liturgia Bogu, we wszystkie godziny, dni, święta, uroczystości, „prowadzi do uwielbienia Boga w Trójcy Jedynego" ${ }^{33}$. W ten sposób Tajemnica Trójcy Swiętej jest nie tylko „dogmatem przyjętym przez naszą myśl na mocy objawienia”, ale staje się „prawdą praktyczną, mówiącą o nas, o Bożej niewysłowionej wspaniałomyślności względem nas", liturgia bowiem pozwala nam przeżyć to, że jesteśmy „przybranymi dziećmi Ojca, braćmi i współdziedzicami Syna i że w nas mieszka Duch Swięty" ${ }^{34}$. Kościół spełnia w ten sposób główną swą misję, którą jest, jak uczy Opat, „doprowadzenie (ludzi) do wspólnoty z Bogiem przez liturgię" ${ }^{35}$, „,zjednoczenia wiernych z Bogiem przez misterium ołtarza" ${ }^{36}$. To doprowadzenie ludzi do wspólnoty z Bogiem ,realizuje się stopniowo w czasie, szczególnie poprzez liturgię roku kościelnego, poprzez „powtarzające się cykle liturgiczne opromienione światłem i łaską Bożą" 37. Poprzez liturgię całego roku „Kościół w swej macierzyńskiej trosce” udziela „najskuteczniejszych środków prowadzących do Boga i do zjednoczenia z Nim" ${ }^{38}$, wielbiąc równocześnie Boga przez Chrystusa i w Chrystusie jako jego Oblubienica ${ }^{39}$. Tak więc Kościół poprzez rok liturgiczny, prowadzi do zjednoczenia $z$ Bogiem. Zjednoczenie to jest celem zarówno całej liturgii roku kościelnego, jak i życia poszczególnego człowieka ${ }^{40}$.

Jak Kościół kierowany przez Ducha Swiętego jest Oblubienicą Chrystusa, tak też „oblubienicą jest każda wierna dusza” ${ }^{41}$. Stąd też, to co Duch Swięty dokonał w Chrystusie i w Kościele, dokonuje się w poje-

\footnotetext{
29 Por. AL, Le Carême, 35, 36, 77, 152, 219.

30 AL, Le Temps Pascal, t. III, 485.

31 Tamże, 312, 484, 491.

32 AL, Le Temps après la Pentecôte, t. I, 141-142; t. II, 123.

33 Tamże, 121-122.

34 Tamże, 130; por. tamże, 10, 13.

35 Institutions Liturgiques, t. IV, Paris 1885, 306; por. tamże, 307, 308.

36 Institutions Liturgiques, t. III, Paris $1883^{2}, 83$.

37 AL, Le Temps aprè la Pentecôte, t. II, 12.

38 Tamże.

${ }_{39}$ Institutions Liturgiques, t. I, Paris $1878^{2}, 17$.

$40 \mathrm{AL}$, Le Temps après la Pentecôte, t. I, 299.

41 AL, Le Temps de Noël, t. I, 27.
} 
dynczej duszy, a „narzędziem Jego oddziaływania na dusze” 42 jest właśnie liturgia roku kościelnego. I dlatego zrozumiałym jest, że liturgia roku kościelnego, jak zauważa Opat, po ,tylu wiekach nic nie traci ze swej świeżości, ani ze swej mocy oddziaływania, chociaż rokrocznie ten sam cykl tajemnic Bożych podaje nam do rozważania". Jest w niej ukryta bowiem moc, zdolna doprowadzić „człowieka do zjednoczenia z Bogiem”, „Ta moc odnawiająca się nieustannie w roku liturgicznym”, to „tajemnica Ducha Świętego, nieustannie ożywiającego dzieło liturgii całego ro$\mathrm{ku}$, istniejące w Kościele $\mathrm{z}$ jego inspiracji" 43. Dlatego też słusznie tak pojęta liturgia roku kościelnego stanowi „niezastąpiony środek życia nadprzyrodzonego" 44, „źródło oddziaływania Ducha Świętego na nasze dusze" 45. Przez liturgię roku kościelnego przedłuża się zbawcze działanie Jezusa Chrystusa. „Liturgia jest nie tylko nieustannym głoszeniem dzieł Bożych”, ale jest „ściśle związana ze zbawczymi wydarzeniami raz jeden dokonanymi w czasie, których istotna rzeczywistość jest nienaruszalna" 46. Sprawowanie liturgii świąt, uroczystości, różnych obchodów „nie jest wcale jakimś tylko przedstawieniem, które ukazuje się naszym oczom. Ono nam przynosi specjalne łaski, które sprawiają w nas to, co oznaczają" 47. Przez liturgię roku kościelnego Duch Swięty sprawia, że „boskie misteria przenikają w nas”, dzięki nim my „żyjemy życiem nadprzyrodzonym, które Syn Boży zdobył dla nas przez swą mękę i zmartwychwstanie" 48. Liturgia roku kościelnego, w ujęciu Guérangera, jest więc realizacją misterium Chrystusa i Kościoła w Duchu Swiętym. To w Kościele, w liturgii roku kościelnego, Chrystus Zmartwychwstały kontynuuje przez Ducha Świętego dzieło zbawienia i uświęcenia.

\section{MISTERIUM PASCHALNE}

Opat z Solesmes mówiąc o misterium roku liturgicznego stwierdził, że uczestnictwo w nim daje udział w życiu nadprzyrodzonym, które zdobył Jezus Chrystus „przez swą mękę i zmartwychwstanie”. I tu nasuwa się pytanie: czy Guéranger pisał o misterium paschalnym, zwłaszcza w omawianym „L'Année liturgique” i co przez nie ewentualnie rozumiał? Ten problem zasygnalizował dopiero w 1975 roku J.Ph. Lemaire w referacie poświęconym trwałym, aktualnym wartościom L'Année liturgique,

42 AI, L'Avent, XXIII.

13 Tamże, XXI-XXIII.

44 Tamże, XVI-XVII.

4. Tamże, XXIII.

46 Tamże, XXI.

47 AL, Le Temps après la Pentecôte, t. I, 4. Por. tamże, 6, 10, 12; AL, L'Avent, XXIV; AL, Le Temps Pascal, t. I. 381; t. III, 140, 208.

${ }_{48}$ AL, Le Temps Pascal, t. III, 369: "Nous vivons de la vie surnaturelle que le Fils de Dieu a conquise pour nous par sa Passion et par sa Résurrection, et que l'Esprit Saint fait pénétrer en nous par le divin mystère de ce jour". 
wygłoszonym podczas Sympozjum ku czci Guérangera w Solesmes. Stwierdził on mianowicie, że ,choć Guéranger nie używał wyrażenia „misterium paschalne" - to jednak miał wyczucie całego bogactwa treści kryjącej się za tym wyrażeniem, poświęcił bowiem jeden tom swego dzieła Męce Pańskiej, a drugi omówieniu Swiąt Wielkanocnych" ${ }^{49}$. Treść tychże tomów wykazuje jednak, że nie tylko Guéranger miał zrozumienie tego zagadnienia, wszechstronnie go omawiając, ale wśród kilku określeń oddających jego sens, użył też terminu: „misterium paschalne” mystère pascal. Najczęściej jednak używał on takich wyrażeń, jak „Misterium Paschy”, „Misterium Zmartwychwstania” 50.

„Co to jest misterium Paschy?" ${ }^{1}$. Na tak sformułowane przez siebie pytanie, Guéranger daje odpowiedź, zawartą głównie w wyżej wspomnianych dwóch tomach, odpowiedź, która w sumie stanowi obszerny wykład. Misterium Paschy rozważa on w kilku aspektach, wskazując naprzód na Paschę żydowską jako na typ nowej Paschy. Następnie omawia tę nową Paschę, Paschę Chrystusa, by z kolei przejść do Paschy w roku liturgicznym i w życiu poszczególnego chrześcijanina. Paschę Chrystusa rozważa Guéranger w świetle Starego Testamentu. „Aby zrozumieć Paschę, trzeba zrozumieć „Misterium Baranka” 52. Omawia więc typy Ofiary Chrystusa w Starym Testamencie (ofiara Abla, Abrahama, Mojżesza), zapowiedzi proroków, aby przejść do „Baranka”, którego wskaże Jan Chrzciciel a następnie do Baranka ukrzyżowanego, zmartwychwstałego i chwalebnego Baranka Apokalipsy. Stąd też inne jeszcze jego określanie misterium paschalnego: „misterium naszego Paschalnego Baranka" i dlatego Święta Wielkanocne - to ,proklamacja panowania Baranka" 53. Opat z Solesmes analizując Paschę Chrystusa na tle Paschy

49 J.Ph. Lemaire, Actualité permanente et vétuste apparente de ,l'Année liturgique" de dom Guéranger, Solesmes 1973, 9.

50 Oto określenie najczęściej używane: „le mystère de la glorieuse Pâque” AL, Le Temps Pascal: t. I, 18, 32, 243; „le mystère de la Pâque - tamże 31, 179, 243, 283; t. II, 179, 357, 445, 569; t. III, 149; „le grand mystère” - AL, Le Temps Pascal, t. I, 317; „admirable mystère de Dieu réssuscité - tamże 393, i „sublime mystère de la Pâque, tamże 151; "des mystères de la mort et de la résurrection de Jésus-Christ" - AL, Le Temps Pascal, t. II, 243. Mówiąc o liturgii wielkanocnej najezęściej używa terminu Pascha (Pâque) z różnymi przydawkami, a bardzo rzadko slowo Wielkanoc (Pâque), np. AL, Le Temps Pascal, t. I, 1, 2, 13, 14, 15, 247.

51 AL, Le Temps Pascal, t. I, 243.

52 Tamże.

53 Nawiązując do słów Apokalipsy: „Oto zwyciężył Lew z pokolenia Judy, Odrośl Dawida, aby otworzyć księgę i siedem jej pieczęci” (Ap 5, 5), daje, idąc za świętym Efremem i za świętym Leonem Wielkim, komentarz do tego tekstu, w którym ukazuje ścisły związek męki i zmartwychwstania Chrystusa: „jeśli jest Lwem to jakże Barankiem? ... W swojej miłości do człowieka, którego chciał odkupić, umocnić niebieskim pokarmem, zechciał ukazać się jako Baranek. Lecz trzeba było, by zwyciężył, jego i naszych wrogów, trzeba było, aby zakrólował, ponieważ została mu dana "wszelka władza w niebie i na ziemi" (Mt 28, 18). W swoim tryumfie, niezwyciężonej mocy, jest on Lwem, któremu nic się nie oprze i które- 
żydowskiej wskazał, że jedna i druga „Pascha” stanowiły „dwa wielkie wydarzenia, objawiające dobroć Boga względem ludzi" 54. Nawiązując zaś do opisu nocy paschalnej i przejścia z Egiptu do Ziemi Obiecanej Prosper wyprowadza paralele między tymi dwoma wydarzeniami. W jednym i w drugim jest „przejście Pana”. Jest i ofiara, tam - baranka, tu - Chrystusa. Tamta Pascha dokonała wyprowadzenia z niewoli egipskiej do ziemi obiecanej, ta zaś wybawienia z niewoli szatana. „Przejście Pana", które wyprowadza z niewoli grzechu, to zmartwychwstanie Chrystusa, to Jego zwycięskie przejście ze śmierci i „opieczętowanego grobu". Ta nowa Pascha ,jest wybawieniem i dla Jezusa i dla Jego braci" 55 .

Chociaż ze względów praktycznych, Guéranger omawiał oddzielnie Mękę Pańską i Zmartwychwstanie, komentując liturgię Męki w jednym tomie, a liturgię świąt wielkanocnych $\mathrm{w}$ drugim, to jednak wiele razy podkreślał on ścisły związek tych tajemnic. I tak, nawiązując, w jednym z komentarzy, do tekstu Apokalipsy (5,5), ukazuje Prosper ścisły związek krzyżowej „Ofiary Baranka i zmartwychwstania pełnego chwały i potęgi” ${ }^{56}$. $\mathrm{Na}$ innym zaś miejscu pisał, że dzieło zbawienia dokonało się „nie tylko przez mękę Odkupiciela, który zmył nasze grzechy w swojej krwi" i nie tylko ,przez zmartwychwstanie, które boskiemu Wybawicielowi dało zwycięstwo nad śmiercią", ale przez „,jedność tych dwóch misteriów $\mathrm{z}$ trzecim, $\mathrm{z}$ misterium uroczystego wniebowstąpienia Tego, który umarł i zmartwychwstał" 57, wtedy to „brama nieba zamknięta" przez grzech, została „ponownie otwarta dla niego i dla nas” ${ }^{58}$. Tak więc Pascha Chrystusa w komentarzu Guérangera jawi się jako cel, ku któremu zmierzała „misja Słowa Wcielonego". Pascha Chrystusa, to „pojednanie człowieka z Bogiem", szczytowy moment zbawczego planu, to „fundamentalna prawda wiary”, „fakt, który potwierdza całą misję Syna Bożego na ziemi”, to „główny przedmiot przepowiadania” Apostołów. „Nie wystarczy (bowiem) wierzyć w Jezusa Chrystusa ukrzyżowanego - pisał jeśli się nie wierzy w Jezusa Chrystusa zmartwychwstałego" 59. Wielkanoc zaś w jego ujęciu, to „pierwszy dzień z dni” nowego Stworzenia ${ }^{60}$.

go zwycięstwo rozbrzmiewa po całym świecie... dla nas jest Barankiem, a Lwemdla wrogów, łącząc moc z łagodnością. To jest pełne misterium Paschy: Jeden Baranek tryumfujący, posłuszny i uwielbiony". AL, Le Temps Pascal, t. I, 247-248, 264.

54 Tamże, 19.

55 Por. Tamże, 141, 268-270.

56 AL, Le Temps Pascal, t. I, 248: „Pour nous Agneau, Lion pour ses ennemis; unissant désormais la force à la douceur. C'est le mystère complet de la Pâque: un Agneau, triomphai, obéi, adoré".

57 AL, Le Temps Pascal, t. III, 224. AL, Le Temps Pascal, t. I, 33.

58 Tamże.

59 Tamże, 33. Por. tamże, 1, 2, 75, 350.

60 Tamże, 3. 
Według Guérangera Pascha Chrystusa zajmuje centralne miejsce w całym życiu Chrystusa i Jego dziele zbawienia. Tak też, w myśl komentarzy liturgicznych Opata z Solesmes, święto Zmartwychwstania Chrystusa będące według starożytnego określenia „uroczystością nad uroczystościami" ${ }^{61}$, stanowi ośrodek liturgii całego roku kościelnego. Dlatego te $\dot{z}$ rocznica tego najdonioślejszego wydarzenia jest każdego roku wielkim dniem, dniem radości, „dniem par excellence” - kontynuuje Guéranger. Ten dzień jest centrum, ku któremu ,zmierza cały rok liturgiczny" 62. W konsekwencji, tym centrum jest cały okres wielkanocny od Swiąt Zmartwychwstania do Zesłania Ducha Swiętego. Jest on ,,jednym wielkim świętem" ${ }^{63}$. To na tym "wielkim święcie" jest zbudowany cały rok liturgiczny i ku niemu zmierzają wszystkie poprzedzające okresy liturgiczne, stanowiąc przygotowanie do niego. „Pobożne oczekiwanie adwentu, pełen serdecznej radości okres Bożego Narodzenia, poważne i surowe refleksje przedpościa, skrucha i pokuta Wielkiego Postu, wstrząsający okres Męki" 64 — to wszystko zmierza do tego jednego punktu, którym jest uroczystość paschalna mieszcząca w sobie „dwa wielkie misteria - Paschy i Zesłania Ducha Swiętego" 65. Właściwym klimatem tych świąt jest „radość duchowa”, „radość Zmartwychwstania”, „radość paschalna" ${ }^{66}$, radość Oblubienicy-Kościoła. Podstawą tej radości jest obecność Zmartwychwstałego Pana w Kościele, w liturgii. Ta radość paschalna opromienia zresztą i pozostałe okresy liturgiczne.

W okresie Wielkiego Postu, gdy Kościół rozważa w atmosferze pokuty Mękę Chrystusa, Guéranger przypomina, że „Jezus na Krzyżu i Jezus Zmartwychwstały, to zawsze ten sam Jezus" ${ }^{67}$. W okresie wielkanocnym w jakiś jednak szczególny sposób Kościół, poprzez liturgię pozwala nam uczestniczyć w paschalnej radości, prowadzi nas do spotkania ze Zmartwychwstałym. Nawiązuje do spotkania i rozmowy Chrystusa Zmartwychwstałego $\mathrm{z}$ uczniami na drodze do Emaus, aktualizuje tę sytuację: ,Jezus jest blisko nas, on do nas mówi, poucza nas, pociesza. A nam jakże dużo potrzeba czasu, by rozpoznać, że to jest właśnie Jezus" ${ }^{68}$. To poprzez liturgię Kościoła, ,mimo upływu tylu wieków, może-

61 Tamże, 1.

62 Tamże, 2.

63 Określenie to nawiązuje do homilii świętego Ambrożego (In Lucam, lib. VIII, cap. XXV), który ten okres świąteczny uważał „za jakby jedną niedzielę wielkanocną". Tamże, 17.

64 Tamże, 18.

65 Tamże.

66 Por. tamże, 27, 30; 171, 172, 237, 247, 249.

67 AL, La Passion et la Semaine Sainte, 30. Ta obecność tajemnic życia Chrystusa w liturgii budzi podziw dom. Guérangera: „O wieczności naszych tajemnic, których nie można przeniknąć, 'Baranek zabity od początku świata' uobecnia tu swoja ofiare, oto raz zrodzony z Dziewicy Maryi, nie przestaje rodzić się w ludzkich duszach". AL, Le Temps de Noël, t. I, 35.

68 AL, Le Temps Pascal, t. I, 234. 
my uczestniczyć w przeżyciach czystej, niewysłowionej radości, której zakosztowali w tym dniu (zmartwychwstania) Maryja, Matka Zbawiciela, Magdalena, jej towarzyszki, Piotr, uczniowie z Emaus i zgromadzeni Apostołowie. Nic tu nie zostało zatarte. Wszystko jest żywe, wszystko się odnawia”. „Jezu, kończy Opat swe rozważania modlitewną strofą, Ty jesteś zawsze ten sam i Tyś jest naszą Paschą. Każda uroczystość wielkanocna jest tą samą Wielkanocą, która była świadkiem Twego wyjścia z grobu. Wszystkie czasy należą do Ciebie; a świat dusz żyje dzięki Twoim misteriom tak jak świat materialny podtrzymuje Twoja Wszechmoc" ${ }^{69}$. Do takiego pojmowania świąt liturgicznych czerpał Guéranger zapewne inspiracje w nauce świętego Leona Wielkiego, którego cytuje często i obszernie. Z jego kazania na Wniebowstąpienie przytacza między innymi zdanie, które zdaje się być podtekstem jego liturgicznego komentarza. Otóż święty Leon stwierdziwszy, że Jezus Chrystus, po ogłoszeniu Ewangelii i zawarciu nowego przymierza, przez wniebowstąpienie położył kres obecności widzialnej tu na ziemi i zasiadł po prawicy Ojca aż do momentu, gdy znów przyjdzie jako Sędzia żywych i umarłych, dodaje: „Tak więc, to wszystko co było widzialne tu na ziemi w naszym Odkupicielu przeszło w porządek obrzędów, aby zaś wiarę naszą pogłębić i ożywić, możliwość widzenia Chrystusa została zastąpiona pouczeniem, którego autorytet opromieniony bożym światłem, przyciąga serca wierzących" 70. Tak też uczył Guéranger. Udział w liturgii roku kościelnego winien doprowadzić na płaszczyźnie wiary do spotkania z Chrystusem Zmartwychwstałym i do osobistego uczestnictwa w samej Tajemnicy Zmartwychwstania.

Pascha Jezusa Chrystusa - „Przejście”, „Przejście ze śmierci do życia" dokonała się „dla Jezusa i wszystkich jego braci”. Jezus umarł i zmartwychwstał ,dla nas" "71. Pascha Chrystusa staje się "naszą paschą" w pierwszym rzędzie przez chrzest. „To jest ta nasza Pascha, 'Przejście' poprzez wode do Ziemi Obiecanej”, ,nasze przejście ze śmierci grzechu pierworodnego do życia laski”, to jest „,szczęśliwa wędrówka (...) z Egiptu tego świata do Kościoła chrześcijańskiego" 72. To w wodzie chrztu zanurzony został nasz człowiek grzeszny, ,jak Chrystus w grobie”, a wynurzenie $z$ wody chrzcielnej jest naszym narodzeniem, zmartwychwstaniem z Chrystusem. „Tak samo jak Odkupiciel nie pozostał w grobie lecz zmartwychwstał do nowego życia, tak też, według nauki świętego Pawła (Kol 2,12), ochrzczeni zmartwychwstali razem $\mathrm{z} \mathrm{Nim}$, w momencie gdy wychodzili $z$ wody otrzymując zadatki nieśmiertelności i chwały, stając

69 Tamże.

70 De Ascensione Domini, Sermo II. Por. AL, Le Temps Pascal, t. III, 274.

71 Por. AL, Le Temps Pascal, t. I, 141, 202, 207, 293.

72 Por. tamże, 290, 292-293. 
się żywymi i prawdziwymi członkami Głowy, która odtąd nie ma już nic wspólnego ze śmiercią. To jest Pascha, Przejście ze śmierci do życia" 73. Przez chrzest dokonuje się ,wszczepienie w Chrystusa" ${ }^{74}$. Udzielenie tego nowego życia zmartwychwstałego Chrystusa, stanowi misterium „dopełniające Zmartwychwstanie Boga-Człowieka" 75. Owo życie ma dokonać $\mathrm{w}$ nas całkowitej przemiany (transformation) w Chrystusa ${ }^{76}$. Uczestnictwo w sakramentach, zwłaszcza w Eucharystii i w liturgii roku kościelnego pogłębia $z$ roku na rok proces owej „transformacji” w Chrystusa. Uroczystości, które celebruje Kościól w swym obchodzie rocznym, udzielają „nowego życia”, „podtrzymują go i rozwijają" 77. Wzrost tego nowego życia, to wzrost wiary, nadziei, miłości. Życie nadprzyrodzone, wysłużone przez mękę i zmartwychwstanie Chrystusa, za sprawą Ducha Swiętego udzielane jest przez „misterium tego dnia" ${ }^{78}$, pisze Guéranger, w tym wypadku odnośnie liturgii dnia Zesłania Ducha Swiętego.

Ta - można by nazwać - „duchowa pascha”, „misterium Paschy spełnione w nas" 79 , będzie mieć spełnienie w powszechnym zmartwychwstaniu. I tu należy podkreślić, że Guéranger tę prawdę o powszechnym zmartwychwstaniu bardzo mocno akcentuje, wydobywając ją, jak sam zaznacza „,z zapomnienia" ${ }^{80}$. Podkreśla równocześnie ścisły związek misterium zmartwychwstania Chrystusa z misterium Kościoła. Zmartwychwstanie Chrystusa i Jego wniebowstąpienie, to dopiero uwielbienie Głowy. Ma być ono jednak uzupełnione przez zmartwychwstanie Ciała i właśnie wszystkie misteria roku kościelnego przygotowują dopełnienie tej tajemnicy. Zmartwychwstanie $\mathrm{w}$ dniu ostatnim będzie prawdziwą Wielkanocą, ,ostatnią fazą” odkupienia człowieka, „uwielbieniem całej natury ludzkiej", będzie ono bowiem ostateczną konsekwencją zmartwychwstania Chrystusa. „Zmartwychwstanie Chrystusa i nasze tak ściśle się łączą z sobą, że właściwie stanowią nie dwie oddzielne ale jedną prawdę" ${ }^{81}$. To zmartwychwstanie będzie też ostatecznym „przemienieniem w Jezusa Zmartwychwstałego", stanowiąc owoc daru łaski, ale i „naszej wierności” dochowanej Zmartwychwstałemu Chrystusowi 82. $\mathrm{W}$ ten sposób Wielkanoc obchodzona na ziemi przemieni się w „Wielka-

\footnotetext{
73 Tamże, 213.

74 Tamże, 381.

75 AL, La Passion et la Semaine Sainte, 703. Por. tamże, 150-151.

76 Tamże, AL, Le Temps Pascal, t. II, 151.

77 Tamże, AL, Le Temps Pascal, t. I, 381; t. III, 249.

78 Tamże, AL, Le Temps Pascal, t. III, 369.

79 Tamże, AL, Le Temps Pascal, t. II, 445.

80 Tamże, 322.

81 Tamże, 322. Por. tamże, 318-319 oraz AL, Le Temps Pascal, t. II, 233, 322,

82 Tamże, AL, Le Temps Pascal, t. II, 619.
} 445 .

21 - Analecta 
noc wieczną" ${ }^{83}$. Będzie to zarazem „szczęśliwe przejście $z$ boskiej uczty tu na ziemi (Eucharystia) do szczęścia wiecznego zjednoczenia" ${ }^{84}$.

Tak więc liturgia roku kościelnego, ucząc „umierania razem z Chrystusem - naszą ofiarą" Wielki Post), aby żyć „radością duchową, którą żyją dusze zmartwychwstałe razem z Jezusem Chrystusem" ${ }^{85}$ (okres wielkanocny), wprowadza nas $\mathrm{w}$ samo Misterium paschalne. W ten sposób rok liturgiczny doprowadza nas do kresu zbawczego planu, do „Paschy wiecznej". W takim ujęciu życie chrześcijanina wyraża się, po prostu we wspólnocie życia z Chrystusem Zmartwychwstałym. Misterium paschalne, jak wyjaśnia Guéranger, ,nie może pozostać bez śladu na ziemi. Jezus Zmartwychwstały wstępuje do nieba, ale równocześnie zostawia w nas zadatek swego Zmartwychwstania”, a my — „winniśmy Go strzec aż do momentu, gdy przyjdzie On powtórnie" ${ }^{86}$. Ten udział w życiu Chrystusa dokonuje się na zasadzie wspólnoty, ścisłej, wewnętrznej więzi, jaka istnieje między Kościołem a Chrystusem, Oblubienicą i Oblubieńcem, Głową a całym mistycznym Ciałem. Wszystkie tajemnice Głowy są wspólne i nam, którzy tworzymy z Panem wspólnotę. „Od Jego przyjścia w ciele, On nie uczynił kroku bez nas. Gdy narodzil się w Betlejem, my narodziliśmy się z Nim; gdy został ukrzyżowany w Jerozolimie, 'dawny nasz człowiek' według nauki świętego Pawła — „został razem z Nim ukrzyżowany". Jeżeli zstąpił do grobu, myśmy zstąpili z Nim, stamtąd, gdy tylko powstał z martwych, już więcej nie umiera, my także zmartwychwstaliśmy i winniśmy wzrastać $\mathrm{w}$ tym nowym życiu, by coraz pełniej 'żyć dla Boga w Chrystusie Jezusie' (Rz 6. 6-10)" 87. Komentując $\mathrm{w}$ dalszym ciągu tekst listu do Rzymian $(6,9-10)$ wyciąga krótką konkluzję, wskazującą na zobowiązanie, jakie płynie z tej wspólnoty ze Zmartwychwstałym Chrystusem: „My jesteśmy Jego własnymi członkami, Jego więc los winien być i naszym. Umrzeć ponownie oznaczałoby wyrzec się Go, oderwać się od Niego, uczynić nieużyteczną dla nas i śmierć i zmartwychwstanie, które stało się naszym udziałem" ${ }^{88}$. Obowiązkiem chrześcijanina jest więc żyć tym nowym życiem, świadcząc wobec świata o zmartwychwstaniu ciał zarówno „w słowach jak i w czynach" 89 .

Misterium paschalne zajmuje więc centralne miejsce w koncepcji roku liturgicznego Guérangera. Zresztą sam to stwierdził, pisząc, że „ktokolwiek posiadł radość wniknięcia pełnym umysłem i sercem w miłość

\footnotetext{
s3 Tamże, 620.

84 AL, Le Temps après la Pentecôte, t. I. 17.

85 AL, Le Temps Pascal, t. III, 27.

86 Tamże, 31.

87 Tamże, $31-32$.

${ }_{88}$ Tamże, 32.

89 AL, Le Temps Pascal, t. I, 322.
} 
i mądrość tajemnicy paschalnej, ten wkroczył w centrum życia nadprzyrodzonego" 90.

Liturgia roku kościelnego, tak jak to podkreślał Opat z Solesmes, ma charakter paschalny. Ma też konsekwentnie i charakter eschatologiczny. Przez liturgię roku kościelnego dokonuje się swego rodzaju "transfuzja” życia Chrystusa w Jego Mistyczne Ciało. Tajemnice życia Chrystusa uczy Opat - „wnikają w nas, wcielają się w nas, każdego roku, a to skutek łaski towarzyszącej obrzędom liturgicznym. Ona to sprawia, że wzrasta w nas, niepostrzeżenie, na gruzach starego, nowy człowiek" 91. To zaś kształtowanie w poszczególnym człowieku Chrystusowego, nowego życia, zmierza do przygotowania Kościoła-Oblubienicy na eschatologiczne spotkanie ze Zmartwychwstałym Chrystusem, aby przez powszechne zmartwychwstanie w pełniejszy sposób włączyć się w liturgię niebieską Chwalebnego Baranka. „Liturgia roku kościelnego, ucząc całym swoim pięknem i poezją wyśpiewać tu na ziemi tajemnice nieba, przygotowuje nas do hymnu wieczności" ${ }^{22}$. I tak każdy adwent ma być tu gorącą prośbą, by Chrystus „odnowił życie w Kościele — Swej Oblubienicy..., by Oblubienica ta stała się piękną..., by była wierną $\mathrm{w}$ miłości..., ponieważ każdy rok przybliża ten dzień, w którym przyjdzie On..., by ją zabrać ze sobą do wiecznego Królestwa" ${ }^{93}$. Tak też liturgia Wielkanocy przygotowuje i wprowadza w Paschę wieczną. „Od Wielkanocy do Wielkanocy zbliża się chrześcijanin do wiecznej Wielkanocy, ... której promienie już dotykają go dziś, dając mu już teraz częściowo zakosztować tej radości, która jest dla niego przeznaczona" ${ }^{94}$. Podobnie Duch Swięty, którego panowanie proklamuje Kościół ,przez liturgię Zielonych Swiąt”, bierze w posiadanie Kościół, by „do końca czasów tę Oblubienicę i Królestwo Chrystusa wspierać, utrzymywać, wybawiać i uświęcać" ${ }^{95}$, aby przygotować ją na przyjście Oblubieńca w dniu ostatnim. Kościół jest więc w sytuacji „Pielgrzyma”, Eucharystia - jest „chlebem podróżnego" 96, Duch Swięty - „Przewodnikiem” 97. Kościół - z dniem każdym przez pustynie świata zbliża się do Świętej, Bożej Góry, celu wędrówki, każdego dnia „oczekując Oblubieńca”, Chrystusa ${ }^{98}$. Na eschatologiczny charakter roku liturgicznego zwraca również uwagę Guéranger, wyjaśniając symbolikę zielonego koloru szat liturgicznych. „Kolor ten wyraża nadzieję Oblubienicy, która wie, że jej los zawierzył Oblubie-

90 AL, Le Temps Pascal, t. I, 18.

91 AL, L'Avent. Préface, XXIV.

${ }_{92}$ Tamże, XXV.

93 Tamże, 276.

94 AL, Le Temps Pascal, t. I, 31.

95 AL, Le Temps Pascal, t. III, 323.

96 AL, Le Temps après la Pentecôte, t. I, 181. Eucharystia: - „le pain du voyageur".

${ }_{97}$ Tamże.

98 Tamże, 275, 281. 
niec Duchowi Swiętemu, pod którego kierownictwem dopełni bezpiecznie swego pielgrzymowania" ${ }^{99}$, co wyraża święty Jan jednym zdaniem: „Duch i Oblubienica mówią: Przyjdź” (Ap 22,17) ${ }^{100}$. W tej eschatologicznej perspektywie, w jaką wprowadza liturgia roku kościelnego, uwydatnia się wartość i sensowność życia ziemskiego: „Czas jest nam dany na to, abyśmy się stali godni Boga" 101.

3. LITURGIA ROKU KOSCIELNEGO MIEJSCEM OSOBISTEGO SPOTKANIA Z CHRYSTUSEM I ODPOWIEDZI NA JEGO ŁASKE ZBAWIENIA

We współczesnej teologii często wskazuje się na dialog, który podejmuje Bóg z człowiekiem. Akcentuje się personalny i egzystencjalny charakter tego dialogu. Stąd też i w teologii liturgii mówi się o dialogu, o spotkaniu. „Liturgia - pisze C. Vagaggini - nie jest monologiem Kościoła, który zwraca swą myśl ku Bogu oddając Mu kult, lecz jest dialogiem Boga i Kościoła, momentem kontaktu i miejscem spotkania" 102. Definiuje się dalej liturgię ,,jako personalne spotkanie z Bogiem przez Chrystusa w Duchu Swiętym" ${ }^{103}$ jako ,zbawczy dialog" ${ }^{104}$. To prawda, że Guéranger nie używał takich określeń, to jednak liturgię i udział w niej pojmował w sensie osobistej odpowiedzi Chrystusowi, współpracy $\mathrm{z}$ udzielaną łaską. Już w swej definicji liturgii, szukając jej genezy, sięga on do zbawczego planu wypływającego $z$ odwiecznej miłości Boga". 'Tak Bóg umiłował świat, że Syna Swego jednorodzonego dał' (J 3,16), aby On wprowadził ten świat w spełnianie liturgii, którą Słowo Wcielone kontynuuje w niebie" ${ }^{105}$. Wyrażeniem i objawieniem tej Bożej miłości a zarazem dziełem liturgii jest - jak uczy Opat z Solesmes całe życie Jezusa Chrystusa, od Wcielenia do Zmartwychwstania. Kościół rozważa to całe dzieło miłości Boga do człowieka właśnie dzięki liturgii roku kościelnego. Stąd widzi on w liturgii całego roku „streszczenie" ${ }^{106}$ zbawczego planu, który ma zrealizować się w poszczególnym

99 AL, Le Temps après la Pentecôte, t. I, 8-9.

100 Tamże.

101 AL, L'Avent, XXIII.

102 C. Vagaggini, Initiation théologique à la liturgie, t. I, Bruges 1963, 30.

103 A.L. Szafrański, Teologia liturgii eucharystycznej, Lublin 1974, 25.

104 F. Blachnicki, Liturgia jako zbawczy dialog, w: Liturgika ogólna (wydanie zbiorowe), Lublin 1973, 95; W. Swierzawski, Mysterium Christi, Kraków 1975, 145: sakrament - ,spotkaniem dwóch osób: Chrystusa i człowieka”.

105 Institutions Liturgiques, t. I, 17.

106 AL, Le Temps après la Pentecôte, t. I, 6. Słowa „abrégé” używal Dom Guéranger kilka razy, w różnych znaczeniach. Poza dosłownym znaczeniem - "skrót”. (Np. AL, Le Carême, 665), oznacza ten termin dzieje duszy, które winny być skrótem, streszczeniem dziejów Kościoła-Oblubienicy, dziejów, w których zrealizować się ma cały zbawczy plan (miejsce cytowane w tekście). Innym razem pisze, że historia Starego Testamentu, Księgi Królewskie - to „proroczy skrót dziejów Kościoła" (C'est l'abrégé prophétique des annales de I'Eglise" - tamże, 7). Tego terminu używa też pisząc o Eucharystii jako o ,pamiątce i streszczeniu” Bożych, 
człowieku. Ten „Boży plan zbawienia świata” spełnia się dziś przez uczestnictwo ,w całym szeregu tajemnic" roku liturgicznego, które zmierzają do tego, by człowiek „,żył i działał według Chrystusa, który jednoczy się z nim za sprawą Ducha Swiętego" 107 poprzez udział w tych właśnie misteriach roku kościelnego. Jeszcze wyraźniej to powiązanie liturgii roku kościelnego $\mathrm{z}$ celem zbawczego planu wykazuje $\mathrm{w}$ innym tekście, który trzeba tu przytoczyć w całości: „Celem, który stawia sobie Kościół święty w roku liturgicznym jest doprowadzenie duszy chrześcijańskiej do jedności z Chrystusem przez Ducha Swiętego. Jest to ten sam cel, który postawił nam Bóg dając nam własnego swego Syna, aby był naszym Pośrednikiem, Nauczycielem i naszym Odkupicielem i zsyłając nam Ducha Swiętego, by w nas zamieszkał. Taki jest cel, ku któremu zmierzają wszystkie obrzędy, modlitwy, w których uczestniczymy. Obrzędy te nie są tylko wspomnieniem tajemnic, których dokonała dobroć Boża dla naszego zbawienia, lecz równocześnie udzielają uczestniczącym w nich łask, które odpowiadają poszczególnym celebrowanym tajemnicom. Te nadprzyrodzone pomoce mają zaś doprowadzić rozwój życia Bożego w nas do 'miary wielkości według Pełni Chrystusa' (Ef 4,13)" 108. Tekst ten wskazuje, iż Guéranger dostrzegał związek Zbawczego Planu z liturgią roku kościelnego i tym samym jej fundamentalną rolę w życiu Kościoła i poszczególnego chrześcijanina. Równocześnie ukazał on, jak ten boski plan wchodzi, przenika w nasz ziemski czas. Dlatego snując rozważania o poszczególnych okresach liturgicznych mówił zawsze o „,mistyce" tego czasu, cały zaś rok liturgiczny nazwał „mistycznym kalendarzem" 109. Miłość Boża objawiona w całej ekonomii zbawienia i proklamowana w liturgii roku kościelnego sprawia, że ta właśnie liturgia chrześcijańskiego roku jest równocześnie wezwaniem skierowanym do człowieka i momentem ludzkiej odpowiedzi. Wyraża tę ideę bardzo wyraźnie Opat z Solesmes w komentarzu na pierwszą niedzielę po objawieniu: „On, który jest życiem, daje się nam cały, przeto i my winniśmy Mu złożyć w naszym sercu, hostię żywą, świętą i miłą Bogu, która przez

zbawczych czynów, zrealizowanych dla nas a obchodzonych w ciągu roku liturgicznego: „Tous les mystères que nous avons célébrés jusqu'ici étaient contenus dans l'auguste sacrement, qui est le mémorial et comme l'abrégé des merveilles que le Seigneur a operées pour nous" (tamże - 169). W dwu wypadkach używa synonimu: "résumé". Mianowicie mówi o człowieku, że to "streszczenie dzieła stworzenia", łączy bowiem w sobie świat materii i świat ducha: „Mais dans l'homme seul, résumé des mondes, à la fois esprit et matière, se retrouvèrent l'expression complète de la pensée créatrice" (tamże, 231). Analogicznie w Eucharystii widzi „streszczenie”, szczyt wszystkich Bożych dobrodziejstw. „L'Eucharistie qui résume tous les beinfaits divins est en même temps l'Action de grâces la plus parfaite et la seule digne que nous puissions offrir à la suprême majesté". Tamże, 230.

107 AL, Le Temps de Noël, t. I, 290.

$108 \mathrm{AL}$, Le Temps après la Pentecôte, t. I, 10.

109 AL, L'Avent, XV. 
wierność łasce Bożej zasługuje na przyjęcie" ${ }^{110}$. Choć Guéranger nie użył słowa „dialog” w swych komentarzach liturgicznych, to jednak dostrzegał w liturgii roku kościelnego kontynuację dialogu, jaki podejmuje Bóg wychodząc ze swym zbawczym planem do człowieka. Posługiwał się on przy tym wyrażeniami nawiązującymi bądź do tekstów bądź do wydarzeń biblijnych. Mówił na przykład, że Chrystus poprzez rok liturgiczny ,,puka do drzwi serc”, „szuka” serca, które „mogłoby użyczyć Mu gościny" 111 .

Liturgia roku kościelnego powtarzając się od nowa każdego roku, stwarza szerokie szanse podjęcia i pogłębienia tego niezwykłego dialogu. Jest jedna różnica - wyjaśnia Guéranger - między drogą Kościoła Oblubienicy a drogą poszczególnej duszy, że „kościół tę drogę od zesłania Ducha Swiętego aż do paruzji przebiegł tylko jeden raz, gdy poszczególna dusza odnajduje $w$ roku liturgicznym tę drogę co roku" 112. Jest to wciąż nowa okazja podjęcia dialogu z Bogiem i pogłębienia go. „Winniśmy być wdzięczni Bogu - dodaje - że przychodzi w ten sposób na pomoc naszej słabości, wznawiając $w$ nas sukcesywnie, porzez świętą liturgię, te pomoce, dzięki którym jesteśmy w stanie dotrzeć do szczęśliwego końca, do którego też jesteśmy przeznaczeni" ${ }^{113}$.

Rzecz jasna, że aby mówić w ogóle o dialogu w liturgii, konieczny jest świadomy $\mathrm{w}$ niej udział. Guéranger, mimo, że jest obrońcą i miłośnikiem języka sakralnego w liturgii, a więc języka zasadniczo niezrozumiałego dla ogółu, języka, który miał stać na straży „tajemnicy”, to jednak doskonale rozumiał potrzebę świadomego udziału w liturgii świąt i cyklów roku kościelnego. W swoim wprowadzeniu do L'Année liturgique stawia jasną zasadę: „Liturgia o tyle zbawczo oddziaływuje na narody, o ile jest zrozumiałą" 114 . A więc pierwszym warunkiem uczestniczenia w liturgii roku jest znać tę liturgię, rozumieć ją, wnikać w jej sens. A to zrozumienie pozwala coraz pełniej odczytać w liturgii objawienie kochającego Boga i szukającego człowieka. Trzeba dodać, że Guérangerowi idzie nie tylko o poznanie intelektualne, lecz o poznanie ,sercem", o poznanie, któremu towarzyszy miłość. Dlatego apeluje do dzieci Kościoła, by ,rozprzestrzeniły swe serca, zwracając się do Boga modlitwą swej Matki", wtedy bowiem liturgia stanie się dla nich „naturalnym źródłem, które ożywiać będzie ducha pobożności" 115. Uczestniczyć w liturgii znaczy przyjąć dar łaski towarzyszącej liturgii i z nią współpracować. Każdy z nas w liturgii może stać się, ,za dotknięciem Ducha Swiętego in-

110 AL, Le Temps de Noël, t. I, 194.

111 AL, L'Avent, 22.

$112 \mathrm{AL}$, Le Temps après la Pentecôte, t. I, 6.

113 Tamże, 6 - 7.

114 AL, L'Avent, $\mathrm{X}$.

115 Tamże. 
strumentem w wielkiej harmonii chwały Bożej"116. Aby ten instrument mógł włączyć się w tę Bożą harmonię potrzebne jest jego „dostrojenie się". Stąd wszystkie rozważania liturgiczne Opata mają wybitnie charakter duszpasterski, zawierając wiele zachęt i wskazań do wspólpracy. Ta współpraca to właściwa odpowiedź człowieka w dialogu z Bogiem. Najdoskonalszym i najpełniejszym wyrazem tego liturgicznego dialogu i świadomego udziału jest Eucharystia, stanowiąca ośrodek całej liturgii. Dlatego każda uroczystość liturgiczna w komentarzach Opata z Solesmes prowadzi do spotkania $z$ Chrystusem w Eucharystii. „Zbliżcie się więc do Niego w Sakramencie utajonego, a życie Boże, którego początki są już w nas złożone, rozwinie się, i spotęguje się Boża moc ogarniająca nasze serca" 117 .

\title{
LA THEOLOGIE DE L'ANNEE LITURGIQUE SELON DOM P. GUERANGER
}

\author{
$\mathrm{R}$ é $\mathrm{s}$ u m é
}

Dom P. Guéranger (1805-1875) excellent rénovateur de l'ordre des bénédictins francais, père, et vrai chef du mouvement liturgique par son oeuvre L'ANNÉE LITURGIQUE contribua d'une façon exceptionelle au renouveau liturgique. L'analyse des commentaires liturgiques d'auteur contenus dans les volumes de L'ANNEE LITURGIQUE nous permet de préciser ses certaines idées conductrices d'interprétation liturgique de l'année ecclésiastique. Dès l'abord, la conception de l'année liturgique de Dom Guéranger c'est l'école de la vie chrétienne, car il mit un accent sur la présence dans l'Eglise de Jésus ressuscité et de l'Esprit-Saint, qui est le Continuateur de l'oeuvre du salut par la célebration du saint sacrifice de l'autel, des sacraments aussi que de la titurgie des fêtes, des solennités, des cérémonies.

Décrivant cette divine opération dans les âmes par la liturgie de l'année toute entiére, l'abbé de Solesmes a employé le terme „mystère”. Par ce terme il exprime la grandeur du dynamisme de l'oeuvre du salut, dont la source est au sein même de Dieu et dont la réalisation s'accomplit dans l'âme du chaque homme par les sacraments et la liturgie de l'année ecclésiastique. Entre cette réalité pleine des richesses exprimée par ce terme et la conception de l'Eglise represéntée par Dom Guéranger - existe une liaison stricte. Dom Guéranger attribue alors à l'Eglise un aspect double. Il la tient pour une société visible, réelle et parfaite, mais en même temps il la perçoit du côté spirituel. Pour lui l'Eglise c'est ,le peuple nouveau". „le royaume”, „le berçail”, ,le temple”, „Corps de Jésus Christ”, „Corps mystique". Mais le plus souvent il la détermine comme „Epouse du Christ” ou ,notre Mère". Ces termes empruntés à la langue biblique, comme aux écritures des Pères de l'Eglise, démontrent le dynamisme intérieur de l'Eglise résultant d'union particulière de l'Eglise et du Christ (Epoux - Epouse) aussi que de ses membres (notre Mère - ses enfants). L'existence de cette union Dom Guéranger souligne à un tel

116 Tamże, XIII.

117 AL, Le Temps de la Septuagésime, 276. 
point, qu'il définit l'Eglise comme, ,le complément du Christ". L'Auteur de cette indissoluble union du Christ et de l'Eglise - c'est l'Esprit-Saint. Et le fruit de cette union de l'Eglise et du Christ par l'Esprit-Saint est la saintété de l'Eglise-Epouse, aussi que sa fécondité spirituelle, grâce à laquelle l'Eglise est une Mère naissante continuellement des nouveaux enfants. Cette opération de l'Esprit-Saint dans l'Eglise s'accomplit entre autres précisément par la liturgie de l'année ecclésiastique.

Ainsi - écrivait l'abbé de Solesmes - la liturgie de l'année ecclésiastique est „un mystère de l'Esprit-Saint, qui féconde incessamment l'oeuvre qu'il a inspiré à la sainte Eglise" aussi que ,le centre de ses apérations dans les âmes”. L'Eglise conduite par l'Esprit-Saint, organise le culte pendant toute l'année liturgique. Et quand nous nous laissons guider par l'Esprit d'Eglise, par cela le Saint Esprit même opére en nous. Par la liturgie de l'année toute entière l'Esprit-Saint nous forme, nous sanctifie, nous unit au Christ et par degrés nous assimile à Lui.

La liturgie de l'année ecclésiastique toute entière, strictement liée avec l'oeuvre du salut, est „une incessante affirmation” et ,une solennelle adhésion aux faits divins qui se sont passés une fois, mais dont la réalité et inattaquable". D'après Dom Guéranger la liturgie de l'année ecclésiastique c'est donc - on pourrait dire - une réalisation du mystère du Christ et de l'Eglise en l'Esprit-Saint par lequel l'oeuvre du salut et de la sanctification est actualisée. Le point central d'une telle conception de l'année liturgique est le mystère pascal du Christ, qui occupe un considérable rang dans ses dissertations surtout, quand Dom Guéranger explique le Temps de la Passion, la Semaine Sainte et le Temps Pascal. La liturgie de l'année ecclésiastique nous enseigne mourir avec le Christ - nôtre Victime (Temps du Carême) pour pouvoir vivre de la joie spirituelle de laquelle les âmes ressuscitées jouissent avec le Christ (le Temps Pascal), elle nous introduit aussi au centre du mystère pascal. C'est pourquoi - explique Dom Guéranger — „quiquonque a le bonheur d'entrer avec plénitude d'esprit et de coeur dans l'amour et l'intelligence du mystère pascal, est parvenu au centre même de la vie surnaturelle". Le développement de la vie surnaturelle au cours de l'année liturgique, qui dans chaque chrétien vise à „la Plénitude du Christ”, prépare l'Eglise-Epouse à l'eschatologique rencontre avec notre Seigneur ressuscité pour s'unir pleinement à la liturgie céleste de l'Agneau glorifié - par une glorieuse résurrection. La liturgie de l'année nous enseigne ici, sur terre de chanter les mystères du ciel, nous prépare en même temps aux hymnes de l'éternité.

Dom Guéranger met toujours un accent tout-à-fait spécial sur le fait, que l'oeuvre du salut réalisée par la liturgie de l'année ecclésiastique en temps terrestre, de la part d'homme exige une coopération et la fidélité. Dans chaque respective saison, il voit tous les éléments contenus dans la doctrine traditionelle de trois oies de la vie chrétienne. Ainsi selon Dom Guéranger l'année ecclésiastique est une authentique école de perfection, qui mène à l'apogée de la sainteté et de la contemplation, une école destinée à tous les enfants d'Eglise. 